Psychology of Language and Communication 2019, Vol. 23, No. 1

\title{
Sciendo
}

DOI: $10.2478 /$ plc-2019-0004

\author{
PIOTR TOMASZEWSKI ${ }^{1}$, PIOTR KRZYSZTOFIAK ${ }^{2}$, EWELINA MORON $^{3}$ \\ ${ }^{1}$ University of Warsaw, Poland \\ ${ }^{2}$ SWPS University of Social Sciences and Humanities, Poland \\ ${ }^{3}$ University of Wroclaw, Poland
}

\section{FROM SIGN LANGUAGE TO SPOKEN LANGUAGE? A NEW DISCOURSE OF LANGUAGE DEVELOPMENT IN DEAF CHILDREN}

\begin{abstract}
...there is no evidence that children cannot learn language via multiple modalities or that using a visual language will hinder the development of a spoken language, but there is strong evidence that not having access to language has long term negative developmental effects.
\end{abstract}

Lederberg, Schick \& Spencer (2013, p. 25)

\begin{abstract}
The aim of this paper is to show shifts in the language development of deaf and hard of hearing children over the last 30 years. The paper presents an overview of Western and Polish studies on education and language development in deaf children in terms of psycholinguistics. Perceptions of the perceptual and cognitive capabilities of such children must be subject to revision and continual methodological reflection due to rapidly changing variables, such as technological progress, social and cultural conditions of primary socialization and the aims of deaf education. Now that an increasing number of deaf children undergo cochlear implantation, and digital hearing aids can provide $70-75 \mathrm{~dB}$ of gain, thus enabling the children to spontaneously develop speech, many of them function in a bimodal environment of the sign and the speech. However, they perform at different levels of educational and developmental success. This paper elucidates the issues of language flexibility in and heterogenization of children using hearing aids or implants on a daily basis.

Key words: cochlear implants, hearing aids, language development, sign language, spoken language
\end{abstract}

Address for correspondence: Piotr Tomaszewski, University of Warsaw, ul. Stawki 5/7, 00-183, Warsaw, Poland. E-mail: tomasz@psych.uw.edu.pl 


\section{Introduction}

Once it was proven that sign language is a complete linguistic system, it was recognized that in the development of deaf children (who were still equipped with less advanced hearing aids rather than with cochlear implants), sign language should be used as the first language as early as possible. It was also assumed that for deaf children, the optimum educational program would be bilingualism that envisages the use of two languages for the teaching of the deaf: a sign language as the first language and a spoken (mainly written) language as the second one. This discourse was used at the end of the twentieth century when the question of access of deaf children to spoken language was a real problem. Today, however, spoken language is increasingly accessible to deaf newborns. This is due to the development of hearing technology (digital hearing aids and cochlear implants), hearing screening, early diagnosis of hearing loss, early intervention for deaf and hard-of-hearing infants, toddlers, and their families.

This situation requires the revision of the language policy which should be appropriate for an increasingly diverse population of deaf children and would inspire the opening of a new discourse of language development for deaf children. Hence, in this paper, we would like to present an eclectic approach to the bilingual education of deaf and hard of hearing children: spoken language and sign language can be acquired in any order, no matter which of them is to be implemented first: this may depend on the diverse cognitive and linguistic abilities of deaf children and on the environment in which they are raised.

\section{Historical changes in the discourse of language development in deaf children}

The European discourse on deaf education and language development in deaf children became ossified in the end of the 19th century for more than one hundred years. In 1880, an international conference of deaf educators was held in Milan, Italy. It is also known as the International Congress on Education of the Deaf. The resolutions voted on by the predominantly hearing delegates banned the use of sign language in deaf schools. The conference thereby promoted the oral method applied by German educators who treated the deaf as cognitively handicapped persons. The preference for using the sign in everyday communication was supposed to be the major factor inhibiting the intellectual, linguistic and social development of deaf children. One hundred years later, in 1980 (20 years after the publication of Stokoe's sign linguistic study), the International Congress on the Education of the Deaf took place in Hamburg, Germany. The participants criticized the dominating oral method ${ }^{1}$

\footnotetext{
1 It is worth noting that the oralist approach is still firmly rooted in some European school and education centers for deaf and hard of hearing children, especially in the Italian and Polish centres (Moroń, Zarzeczny, 2014).
} 
and stressed that the deaf have the right to be educated in their language-sign language.

When, in the 1960s and 1970s, deafness attracted attention as a sociocultural phenomenon in the context of sign language used within deaf communities, Americans were the first to undertake research into the impact of using sign language by deaf children, especially those of deaf parents, on their development. It was observed that those children were better at oral communication with other people and had better educational achievements in reading and writing skills than deaf children of hearing parents who were raised using only spoken language (Meadow, 1968; Montgomery, 1966; Stuckless \& Birch, 1966; Vernon \& Koh, 1970). Back in the 1960s and 1970s, linguistics was another significant line of research. Findings in this field demonstrated that in and of itself, deafness is not the cause of the child's limited development, especially not in respect of language and cognitive skills. It was shown that persons deprived of the ability to hear from birth can naturally acquire a language that supports or contributes to the cognitive development and that the sign language used by such persons don't limit the development of cognitive processes. The first analysis of American Sign Language (ASL) was presented by Stokoe (1960) in his paper Sign Language Structure: An Outline of the Visual Communication Systems of the American Deaf. He argued that natural sign language demonstrates the characteristic universals of spoken languages--except for the sound. Stokoe's deliberations included in that paper became a fertile source of inspiration for research on sign languages across the world. The research results showed that country-specific and local sign languages are complete language systems with both natural language features and social functioning patterns; they are also a distinctive cultural feature of the linguistic minority to which the Deaf ${ }^{2}$ using sign language on a daily basis belong (Brentari, 2010; Pfau, Steinbach, \& Woll, 2012). Polish scholars arrived at similar conclusions. Following preliminary sign linguistic research carried out in the 1990s in Poland, Polish researchers began to see sign language, especially Polish Sign Language (PJM) as a natural language that functions in much the same way as spoken languages do (Farris, 1994; Rutkowski \& Łozińska, 2014, 2016; Świdziński \& Gałkowski, 2003; Tomaszewski, 2010, 2011, 2015a). This led to a gradual shift in the approach to deaf people: there was a growing awareness that the Deaf as PJM users are a cultural and linguistic minority and this, in turn, favored the spread of language freedom in the context of unrestricted use of PJM or other signed systems in everyday life and at school as well. We are now witnessing a slow change in the discourse on deafness in Poland. The medical paradigm is still dominant (Moroń 2014; Tomaszewski \& Moroń, 2018) but calls for taking the sociocultural point of view are increasingly common

\footnotetext{
2 The word "deaf" (not capitalized) refers to all deaf and hard of hearing people, regardless of their degrees of hearing loss, whereas the word "Deaf" (capitalized) is a term referred to the social group using sign language, the members of which share similar experiences, beliefs and cultural attributes.
} 
(Podgórska-Jachnik, 2013; Moroń \& Zarzeczny, 2014; Sak 2014; Tomaszewski 2015b; Tomaszewski \& Wieczorek, 2016; Łozińska \& Rutkowski, 2017; Wrześniewska-Pietrzak, 2017).

The increasing knowledge on the structure of natural sign language has been a starting point for the research into the acquisition of this language by a deaf child. To date, many studies have demonstrated high concordance and similarity between the stages of acquisition of language competence in deaf children of deaf parents (in sign language) and the stages of development of the same competence in hearing children (in spoken language) from hearing families (see Chamberlain, Morford, \& Mayberry, 2000; Morgan \& Woll, 2002; Newport \& Meier, 1985; Schick, Marschark, \& Spencer, 2006; Volterra \& Erting, 1994; see also Tomaszewski, 2003a). The consecutive stages of acquisition of signed language and spoken language are parallel and include: babbling (7-10 months), first-word stage (12-18 months), two-word stage (18-22 months), stage of word modification and rules for sentences (22-36 months) (Newport \& Meier, 1985). It has been understood that in both the groups, the milestones in the language development are achieved at the same age, irrespective of the child's language modality, perception of stimuli and hearing capabilities.

The development of deaf children under conditions of impaired linguistic stimulation was also taken into account when the linguistic acquisition was not complete. For the Polish studies on language development of deaf children, conducted in the late 20th century, or at a time when the auditory technology was less advanced, we can single out two paradigms: the medical (dominant) paradigm and the sociolinguistic (emerging) one. Both are based on the observation independent of the adopted research methods: deaf children and hard of hearing children (or, in the medical paradigm: "children with hearing impairment" or "children with hearing loss") have enormous difficulty acquiring spoken language, especially in comparison with their hearing peers (cf. Tomaszewski, 2000, 2001). In the medical paradigm, these problems result from the children's failure to learn the speech patterns--according to the structural model of language--of lower-order units (phonemes); this failure precludes the possibility of learning higher-order units (morphemes, lexemes, etc.) (Krakowiak, 1995). These observations are confirmed by Western studies: Verifying the oral method, Schlesinger and Meadow (1972) observed that $75 \%$ of their study subjects (deaf children aged about 4) used a vocabulary and reproduced grammatical structures on the acquisition level of a two-year-old child. Gregory and Bishop (1982) also showed that the idiolect of 16 out of 24 deaf subjects who were starting their education contained less than 150 words, compared to the about 2,000-word vocabulary of their hearing peers (Hodgson, 1953). The sociolinguistic paradigm highlights the child's perceptual abilities to acquire language using the visual-gestural modality (Dziemidowicz, 1996; Tomaszewski, Łukaszewicz, \& Gałkowski, 2000). 
In earlier American research, observation was made of the linguistic behavior of deaf preschoolers who had not had previous contact with peers or adults using ASL. It turned out that the children who were being studied, despite their lack of contact with ASL, had created a system of signs which were collectively labeled home sign. The children were referred to as homesigners (see Goldin-Meadow, 2003). It was observed that this system was comprised of linguistic elements which to some degree supported the nativist theory stressing the existence of a biological basis of linguistic competence. Nonetheless, biological factors as well as a sufficiently rich language environment are dependent upon one another and this co-dependence guarantees each child the possibility to adequately acquire a given language. This is confirmed in the studies that observed the birth and development of language among Nicaraguan deaf children of hearing parents who were not exposed to any conventional sign language (Helmuth, 2001; Kegl, 1994; Kegl, Senghas, \& Coppola, 1999; Senghas, 1995; Senghas \& Coppola, 2001). That took place in Nicaragua, Middle America, where a community of those children created their own sign language. In the early 1980s, the children started their education in Managua; they got in classes taught by hearing teachers who had no command of any signed language. The studies showed that, in spite of the lack of contact with sign language, the Nicaraguan deaf children created, on their own initiative, a kind of signed pidgin based on their home sign systems. The pidgin was called a language of Nicaraguan signs (Lenguaje de Signos Nicaraguense). On the ground of that system, the next wave of young deaf children quickly developed a grammatically more complex language named Nicaraguan Sign language (Idioma de Senas de Nicaragua $)^{3}$. Similar research was carried out in Polish circumstances: When homesigners as "pre-school signers" entered into peer relationships with each other, a process of pidginization occurred (Tomaszewski 2003b). At this level, those children finding themselves in the role of "language moderators" (with different systems of home sign) influenced each other and spontaneously originated new language creations, which might lead to the emergence and formation of a pidgin sign system. In accordance with Jackendoff's (1999) theory of natural language evolution, this system constitutes a transitional phase between the stage in which different home sign systems function at home and the one in which a modernized full sign language appears. As the results of Tomaszewski's $(2003 \mathrm{~b}, 2006)$ research indicated, new linguistic elements occur in a pidgin sign system, ones which are not found in the earlier home sign systems and which appear to require signing contact among pre-school signers.

It this context, it can be added that the issue of the critical period in child development is set in the area covering the study into deaf children's ability to use sign language. The age at which deaf children learn sign language significantly affects their knowledge of the sign in later stages of their development. A number

\footnotetext{
${ }^{3}$ Still other studies have shown the emergence of sign language among three generations of deaf people and their families in a Bedouin community in the Negev desert (see Senghas, 2005).
} 
of experimental studies have been conducted to assess language competence of deaf adults exposed to sign language at different periods of their development. They showed a negative correlation between the age of sign language acquisition and the fluency in using the sign language phonology, morphology and syntax (Mayberry, 1994, 1995; Mayberry \& Eichen, 1991; Mayberry \& Fisher, 1989; Newport, 1990). Similar results have also been obtained in preliminary studies to investigate the impact of the critical period in language development on the command and fluency in Polish Sign Language achieved by deaf individuals raised under different conditions of language stimulation (Krzysztofiak, 2017; Majewska, 2016). To sum up the above observations, the lack of exposure to language in the early years of life can be considered to possibly contribute to decreased fluency in sign language. Mayberry (2010) refers to this, too, bringing up the question of the lack of proper measures to support deaf children in this regard, despite the awareness of the importance of age of language acquisition.

As has been observed, deaf children (especially those of hearing parents) who had limited opportunities to learn spoken language, relied more on their language abilities on the grounds of the visual-gestural modality. Hence, a thesis has been advanced that such children can gain greater cognitive advantages from using signed language--and this is why simultaneous communications (SimCom; simultaneous signing and speaking) began to be used. In the United States, that model "was developed by educators in the 1960s and 1970s to capitalize on DHH children's relative ease of acquiring sign" (Lederberg, Schick \& Spencer, 2013, p. 17). Under Polish conditions, the equivalent of SimCom, called system językowo-migowy (SJM, word for word: languagesign system; also known as manually-coded Polish language system and as Signed Polish) was introduced and spread in the late 1980s and early 1990s (Tomaszewski \& Sak, 2014). That strategy was adopted in order to make it easier for deaf pupils to achieve language competence in spoken language (e.g., English, Polish). SimCom was to ensure full reception of the visual structure of spoken language in terms of semantics and syntax. The use of SimCom consists in visualizing the grammatical structure of spoken language by subordinating the signs to the spoken language grammar. Some were skeptical about the SimCom method, believing that this form of communication would become unacquirable to those deaf children who only used the visual channel to receive the spoken language grammar components shown to them manually (Gee \& Goodhart, 1988; Johnson, Liddell, \& Erting, 1989; Gee \& Mounty, 1991, Tomaszewski, 2006). "From the linguistic point of view, only Polish Sign Language is a language (...). SJM is a limited subcode of Polish. This means that it is a signed (gestural) variant of Polish. SJM uses the Polish grammar and selected signs [of Polish Sign Language]. It does not develop its own grammar, hence it is a mode of communication (not a language!) that will be more quickly mastered by hearing people than by the Deaf" (Moron, 2014, p. 26). That view 
was confirmed by Supalla's study (1991) which demonstrated that deaf children of hearing parents who only had contact with the manual system of spoken language displayed, anyway, a strong tendency to create language structures similar to those of natural sign language, instead of processing the manual and oral patterns imposed on them from outside. So, the behavior of those children who had no physical access to spoken language has shown that the perception of the manual variant of spoken language is difficult and burdensome to people who function in the world relying on their visual capability (Tomaszewski \& Bandurski, 2007). That is why some researchers arrived at a conclusion that young deaf children should, in the first place, develop their natural sign language skills and then be taught to read and write (Grosjean, 2001; Padden \& Ramsey, 2000; Wilbur, 2000).

Also, large amounts of data have been collected about the development of communicative competence in deaf children, displayed in action and topical discourse analyzed in the dyadic interaction unit (Day, 1986; Grenberg, 1980, Lederberg \& Everhart, 1998, 2000, Meadow et al., 1981, Nicholas, 2000, Nicholas, Geers, 2003; Prinz \& Prinz, 1985; Tomaszewski, 2008a, 2008b). Exploratory research on the development of narrative skills in deaf children was also undertaken (Tarwacka, Tomaszewski, Szymańska, \& Bokus, 2014). The reason for which these studies were initiated was the criterion of a significant novelty: in Poland, there were no studies whatsoever on narrative discourse of deaf children whose natural language was PJM.

The results of the said research prove that, regardless of the type of modality of language, deaf children can manifest language activity in the process of play and active, narrative discourse, and they can also effectively engage in social interactions by initiating and maintaining conversations in visual-gestural language. PJM then plays an essential role in the development of linguistic creativity of deaf children, and being deaf need not be an obstacle in language acquisition. Insufficient or absent early and constant exposure to a perceivable language can lead to lowered linguistic or communicative competence.

Tomaszewski and Ruszkowska (2014) also conducted further comparative research among deaf children and hearing children of hearing parents (HCHP), the results of which indicated that the visual modality dominant in deaf children using PJM and the auditory modality dominant in hearing children using spoken Polish do not distinguish these children with respect to the possibility of manifesting linguistic and communicative competence. It was observed that there are certain "uniting" types of linguistic and non-verbal behaviors that are typical of visual and phonic communication between these groups.

The research confirmed that deaf and hearing children can develop linguistically in a similar way, however some differences were also noted. For example, in the process of play and activity discourse, hearing children asked questions and provided instructions or explained ways of action much more frequently, compared to deaf children (Tomaszewsk \&, Ruszkowska, 2014). 
As was the case with narrative discourse: When the results of the research presented here were compared with earlier research in which the subjects were hearing children, differences were found between the structures of narrative texts created in spoken and signed languages (Bokus, 1991; Bokus \& Shugar, 1995, 1998; Tarwacka et al., 2014).This raises another question, namely, whether these differences constitute an indicator for the cognitive level of deaf children (as an effect of education) or rather a consequence of the specifics of language modality (of sign language). It might turn out that this is more a consequence of how parents and teachers raise these children in a cognitive linguistic context. The role of the parents and teachers in the education and the primary and secondary socialization of deaf children in the linguistic and cognitive context can most likely not be overestimated. Hence it is necessary to take into account and examine the complexity of the interactive and cumulative nature of development where three inter-related aspects function, namely language, learning and experience (Marschark \& Hauser, 2012). In this way, it will be possible to capture the differences between deaf and hearing children as well as those among deaf children themselves and thereby to better understand that deaf children's needs or predispositions are sometimes very different from those in hearing children. This, of course, does not necessarily indicate that deaf children have insufficient cognitive capability. Both groups may receive identical conditions for development and may in fact develop in a similar way. There is, therefore, no reason to suppose that such differences are either inherent or disadvantageous. Since there are changes in perceiving deaf people in studies on their cognitive functioning: the perception now involves increasing knowledge of the effects of deafness and signed language (and not spoken language only) on an individual's cognitive development. In their discussion on this issue, Marschark and Wauters (2011) identified four periods in the studies on cognitive processes in deaf persons. In the first period (the fifties of the last century), authors pointed out that the level of cognitive functioning was lower in deaf people than in hearing people; in the second period (the sixties), they highlighted the concreteness of thinking (with concomitant "cognitive poverty" of abstract notions) in the deaf; in the third period (the seventies), researchers started to realize that deaf pupils can fulfill non-verbal cognitive tasks at the level of their hearing peers; and in the fourth period (nowadays), the focus is put on the differences in the mental processes in the deaf in relation to those in the hearing. Accordingly, today's studies focus on the different ways of processing information by deaf pupils as the modes of communication and the ways of solving task-based problems they use vary greatly. We currently know that limited communication or lack of communication in any language--in the sense of language deprivation, not of auditory deprivation--leads to scarcity of language information that may affect the deaf child; such scarcity may impair the ability to carry out mental language operations, thus inhibiting the individual's cognitive development 
(Hall, Eigsti, Bortfeld et al., 2016; Humphries, Kushalnagar, Mathur et al., 2016a; Hall, Levin, \& Anderson, 2017).

In addition to the psycholinguistic studies, the first neurolinguistic studies were undertaken in the 1980s to investigate the cases of deaf aphasiacs using ASL. The aphasiacs displayed ASL agrammatisms similar to those displayed by expressive aphasiacs who had formerly used spoken language (cf. Poizner, Klima, \& Bellugi, 1987). This formed the basis for proposing a thesis that the brain representation of sign language competence is linked, just as is the case with language competence in hearing people, to the same structures of the central nervous system. Broca's area is activated in hearing individuals when they are speaking, and in deaf people when they are signing; Wernicke's area is involved in the comprehension of both spoken and sign langauges (Emmorey, 2002, see also 2011).

To sum up: The fact that sign language is a complete language system has triggered the change in the discourse on deaf education that emphasizes the demand for bilingual education for the deaf--with sign language as the first language and spoken language (mainly in written form) as the second one. This curricular solution has been adopted by many schools around the world (see Marschark, Tang, \& Knoors, 2014). In Poland, the foundations of bilingual education for deaf children have been built under experimental conditions by, among other initiators, the Warsaw Institute for the Deaf (cf. Tomaszewski \& Sak, 2014). After introduction of this type of education, studies were carried out to investigate the impact of bilingualism on deaf children's language development. They showed that early bilingualism, i.e. early acquisition of language skills (in signed language and in spoken language in written form) correlates with the development of reading and writing skills (Hoffmeister, 2000; Prinz \& Strong, 1998; Stewart \& Clarke, 2003; Strong \& Prinz, 1998, 2000) and that acquisition of signed language constructed on the grounds of the visual-gestural modality supports the spoken language development (Schirmer, 2001; YoshinagaItano \& Sedey, 2000; Yoshinaga-Itano, 2006; Marschark, 2007). Although the concept of bilingual education for deaf children has a solid theoretical basis, it is still not sufficiently supported by evidence-based practice due to a lack of sufficient data that would allow for evaluation of the language development in deaf children raised under bilingual conditions (sign language and spoken language in written form) in times when they used less advanced hearing aids (Knoors \& Marschark, 2014; Knoors, Tang, \& Marschark, 2014; Mayer \& Leigh, 2010; Spencer \& Marschark, 2010).

Apart from the discursive change in deaf education and, more broadly, in the accessibility of knowledge to deaf and hard of hearing people, two other significant changes are taking place in different countries including Poland. Behind the first change is a revolution in hearing aid technology: today's hearing aids and cochlear implants are increasingly advanced and offer deaf and hard of hearing people an ever-growing access to sounds and spoken 
language. The other change involves the rapid progress in both hearing screening and, in particular, early diagnosis of hearing loss in infants, and in related development support as well. In view of that, the next parts of this paper describe the impact of these two models of change on the paradigm of language development in deaf and hard of hearing children.

\section{Between the past and the present: Towards a new discourse}

Deaf children gain access to spoken language in ways that would have been unimaginable until recently. When familiarizing ourselves with the report by Knoors and Marschark (2012) on new trends in deaf education, we arrive at a surprising conclusion that the issue of inaccessibility of spoken language to deaf children was a real problem at the close of the 20th century but now it is becoming increasingly less topical because the fact that spoken language is becoming more and more accessible to many deaf infants cannot be ignored in any way. This can be attributed to the progress in medical science, and, more particularly to the latest auditory technology developments. These include: hearing screening, early diagnosis of hearing loss in newborns ${ }^{4}$, the latest digital hearing aids (HAs) or cochlear implants (CIs) and early intensive and regular development support. Early diagnosis of hearing loss allows for, on the one hand, the implementation of a suitable auditory rehabilitation program, and on the other, it helps to prepare the family and other people around the child for communication challenges arising from hearing loss. In the child has profound deafness, such a program enables the hearing family, for example, to start learning sign language to be able to immerse the child as soon as possible in a language bath that is fully perceptible to their deaf child. This situation applies to an ever-growing number of deaf newborns or to children who have lost hearing in their early years of life--not only in Poland but also in Europe and all over the world. We witness an increasing number of deaf children acquiring, little by little, a good command of spoken language.

The new situation requires the language policy to be revised and made suitable for the increasingly diverse population of deaf children. The new policy should also provoke scientific reflection on the changing discourse on deafness and, more particularly, on language development in deaf children. The new situation also involves an emic change, that is, a change in the perception of spoken language by the d/Deaf community. A CI was first implanted in a child under 2 years of age at the beginning of the 1990s and here is what Paludneviciene and Leigh wrote a decade later (2011, p. vii):

For many members of the Deaf community, the issue of cochlear implants

has been fraught with trepidation, anger, frustration, and outright rejection of the concept that surgical insertion of an auditory device is required to

\footnotetext{
${ }^{4}$ In Poland, all newborns without contraindications against screening have been screened for hearing loss since 2002 thanks to funding from the Great Orchestra of Christmas Charity.
} 
restore a sense that is "missing." A good number of these members saw it as an attack on a "visual way of living" and on their signed languages. They also feared the loss of their culture, a culture that has been around for centuries, one that was only formally acknowledged as a bona fide culture in the latter half of the 20th century.

There is currently a growing number of members of the Deaf community who begin to accept the CI technology, seeing in it an opportunity to maximize their competence in two languages: signed language and spoken language. Nevertheless, still many members of the Deaf population articulate the view that cochlear implantation in children is a danger to their identity and culture (Potrzebka, Moroń, Tomaszewski, \& Piekot, 2015; Tomaszewski, in press). This paper does not question the sociocultural discourse on deafness according to which sign language is recognized as a natural language and the Deaf communities using this communication tool have a visual culture reflecting their unique ways of looking at the world but it tries to delve deeper into the question of the enormous changes in medical discourse. The study also proposes a balanced vision for the development of deaf children, one that allows for the strengths and limits of both the sociocultural and the medical approaches to deafness.

\section{Changes for the better?}

Early detection of limited hearing is one of the causes of the change in the discourse on deafness ${ }^{5}$. At the turn of the 20th and 21st centuries, the average age at which limited hearing was diagnosed in the USA decreased from 3.5 years to only 2-3 months of age. At present, newborns undergo hearing tests just after birth (Leigh \& Andrews, 2017). This is also the case in Poland--since 2002, infants have been commonly screened for hearing loss on their second day of life thanks to the Great Orchestra of Christmas Charity (GOCC) . $^{6}$ In many countries, early diagnosis of deafness results in decreasing numbers of deaf and hard of hearing pupils in special schools and, at the same time, in increasing numbers of such children in integrated and mainstream schools (Archbold, 2015).

Once limited hearing is early detected, the next step is to early provide the infant with hearing aids or CIs. While in 1990, globally, in a population of 5,000 people with cochlear implants, only $10 \%$ accounted for children, in

\footnotetext{
${ }^{5}$ Spencer and Koester (2016) suggest that instead of terms like "hearing impairment" and "hearing defect" that are construed by many as having wrongfully negative overtones, "limited hearing" be used. In their opinion, this also applies to the term "hearing loss" that is not appropriate in many cases, for example, a baby born deaf has never had any hearing.

${ }^{6}$ In 2015, 8.75\% of screened newborns required further diagnostic testing due to a negative result of the hearing test or to other risk factors. Hearing tests were carried out on 350,020 infants out of the 356,844 infants registered in the GOCC database (the information was collected from the central database of the Universal Infant Hearing Screening Programme run by the GOCC Foundation; date of inquiry: Feb. 10, 2016; date of data download: Feb. 11, 2016).
} 
2002, children made up $50 \%$ of a population of 45,000 deaf people implanted at different ages, (Leigh \& Christiansen, 2003). In 2010, there were already as many as almost 26,000 deaf children with CIs in the USA (NIDCD, 2010). In Northern Europe, $80 \%$ of deaf babies have received a CI since 2006 (Boyes Braem, \& Rathmann, 2010). Worldwide, the proportion has been $40 \%$ since December 2010 (Humphries, Kushalnagar, Mathur et al. 2016b). There are countries where the vast majority of newborn deaf babies receive a CI. For instance, in the Netherlands, even before 2012, more than $90 \%$ of deaf babies had received their CI below 2 years of age (Knoors \& Marschark, 2012). Based on these changes, one should expect to see even more children with CIs--it is estimated that in August 2020, there will be as many as a million more people with CIs around the world (see Christiansen, 2014).

Early diagnosis of deafness or hearing loss and early intervention with hearing aids or CI implantation imply early development support, the top priority of which is to optimize language and social development as well as reading and writing skills in deaf and hard of hearing children (Yoshinaga-Itano, 2013). The thesis that early exposure to language contributes significantly to the higher language fluency levels in later life is supported by some studies into the development of language and communicative competence in children with CIs. There is evidence that children who received their CI at 1 or 2 years of age and were thus exposed to early language stimulation demonstrated at a later age similar--but not identical--language skills in terms of use of speech to those displayed by hearing children (Lenihan, 2010). However, these data refer to those deaf children who received their CI at age between 2 and 4 and in whom significantly worse effects of use of spoken language were observed (see Niparko, Tobey, Thal et al., 2010). Early implantation and speech therapy can help to enhance the ability to hear and to develop speaking skills but, as Marschark, Machmer and Convertino (2016) wrote, there is no clear answer to what the consequences of the use of a CI can be for the general language development in a deaf child. Admittedly, there are scientific reports on progress in early detection of deafness and in early intervention but, based on the broad variety of study reports, one can articulate two main reasons for which CIs can in some cases lead to language deprivation: Firstly, the CI technology does not automatically provide full access to spoken language; secondly, professionals not only do not recommend sign language for learning by young deaf children but they even advise against it, whereas, after all, sign language is crucial for language development in the early years of life (Hall, 2017; Humphries, Kushalnagar, Mathur et al., 2017; Tomaszewski, in press). However, it is noteworthy that the recent observation of language development in deaf children with CIs reflects their predisposition and a close relationship between the age of implantation and the outcomes achieved for both receptive and expressive use of spoken language. Of course, one should not on this basis draw that hasty conclusion that deaf children with CIs performing 
considerably better in terms of spoken language have been completely "cured" of deafness. What is important, first and foremost, is that CIs enhance the ability to hear, thus including the group of deaf persons with CIs in the group of hard of hearing persons with advanced HAs. Since studies have shown that children with CIs increasingly often have better auditory perception and properly react to, identify and localize sound signals, and in some of the children, even the natural articulation and identification of words and phrases improve considerably. The children's willingness to produce verbal utterances is also greater (Franz, Caleffe-Schenck, \& Kirk, 2000; Niparko et al., 2010; Tenenbaum, 2011; Weisel, Most, \& Michael, 2007). The situation where two CIs are implanted in a deaf individual is even more favorable in this respect, because, as shown by the studies by Litovsky and his team (2006), persons with two CIs perform better in terms of identification of the location of sound sources in the environment than persons with one CI or than those with one CI and one HA. It should be remembered, however, that when one or two of their CIs stop working, the users are still deaf, even regressively deaf.

The deaf using CIs cannot hear just as their hearing peers do because their electronically stimulated hearing does not equals the natural perception of auditory stimuli. In the sociocultural approach, deaf persons with CIs have until recently made up a separate group. However, what is noticeable is the development of the "CI discourse" that changes the cultural proportions, increasing the numbers of "hard of hearing" people and not increasing any more the numbers of Deaf people, functioning of whom is primarily based on the visual modality (Tomaszewski, in press). Therefore, the fact that spoken language is becoming the first and primary language to a growing number of deaf children should not be obscured (see Knoors \&Marschark, 2012).

It should also be noted that apart from deaf children who benefit a lot from CIs in the process of acquiring spoken language there are also deaf children who do not benefit to a degree sufficient to learn speaking skills and must rely on the visual stimuli that make up an alternative way for such children to learn a language. This is confirmed in the observation that some children with CIs are still not able to identify simple words and phrases, do not display willingness to speak, do not learn spoken language naturally just as their hearing peers do, and as regards speech understanding, more complicated utterances or orders are not comprehensible to them (Houston, Carter, Pisoni et al, 2005; Barker, Quittner, Fink et al., 2009; see also Spencer \& Marschark, 2003). Recent observations highlighted the number of implanted children who do not succeed in developing open-set speech recognition by the age of 5 years (Barnard, Fisher, Johnson, et al., 2015). Humphries, Kushalnagar, Mathur et al. (2012, p. 196-197) emphasize the great diversity of spoken language competence among deaf children with CIs: 
While there is variability in the success rate and in standards for what constitutes success, there is agreement that some children receive no discernible auditory benefit from CIs. These children cannot distinguish speech sounds from environmental sounds, and they cannot distinguish between environmental sounds. The next group of children displaying more response to implants still do not gain linguistic benefit, but can distinguish among environmental sounds (such as distinguishing between a knock on a door and a fire alarm). The next group up gains only a minimal advantage in speech, such as being able to distinguish the number of syllables in a speech stream but not being able to distinguish words. We argue strenuously that this does not constitute linguistic benefit even if it involves speech units. The next group up can converse with family members and close friends, using speech-reading and context in addition to the auditory information that CIs provide. And the "stars," a term used often in the literature (e.g., David Pisoni), can converse with strangers, but they must use speech-reading and context in addition to auditory information.

The authors suggest that the proportion of children to whom their CI does not ensure full access to spoken language acquired as the first language be conservatively estimated at 20\% (Humphries, Kushalnagar, Mathur et al., 2012, p. 197). It can be assumed that the proportion of such children is in fact higher.

In conclusion: The CI technology can be a useful tool to support the speech development although it cannot fully guarantee that the expected outcomes will be achieved. It can significantly improve the hearing skills and can help to learn spoken language as the first language but it does not make deaf people hearing. In a word: In terms of knowledge of spoken language, deaf children do not function exactly like hearing children and not like deaf children in the past either.

\section{Signed language and spoken language: Which way is the right one?}

With the heterogenization of the population of children with CIs, it is necessary to change the educational system and this is quite a challenge for professionals--the teachers whose approach to the language education of deaf and hard of hearing children have all the time been revolutionizing the spectacular advances in medical science linked to modern auditory technologies. However, it is possible to eclectically work out practical principles for early development support with deaf and hard of hearing children's individual educational needs taken into account. Such children currently represent a wide range of individual profiles. There are children who go the way of fully spoken communication, and others who concentrate much more time toward the signed communication track. In between there is a staggering number of richly diverse configurations, with two languages combined 
to different extents and on different levels. The heterogeneity of the population therefore justifies the necessity to work by employing bimodal speech-sign bilingualism.

Other countries keep up with the constant changes in the language education curricula for deaf children: For many years now, bimodal speech-sign bilingualism has been replacing sign-print bilingualism that was practiced in deaf education in eighties and the nineties of the previous century. One example of this change is the Laurent Clerc National Deaf Education Center based within the premises of the Gallaudet University of Washington (see Nussbaum, Scott, \& Simms, 2012). Bimodal speech-sign bilingualism is also pursued by the Warsaw Institute for the Deaf, specifically the Early Development Support Center (see Adamiec, 2015). This model of bilingualism is guided by the principle of flexibility: one should employ a strategy for fast and easy adaptation to the conditions that evolve depending on the deaf child's and its family's specific situation. Thus, this flexible model of bilingualism takes into account the capabilities and the language and communication preferences of the child and its family; or the expectations, capabilities and limitations of the members of the family in which the deaf person lives. This model also assumes full acceptance for learning and developing skills in two languages--spoken language and the signed one, whereas the order of their acquisition varies in different children. The fact that a deaf child turns more to spoken language or more to sign language should be an important indication, an outcome of thorough observation and objective diagnosis of development. This may guarantee better assurance for the future than teaching the child carelessly in one language only, whether the spoken or the signed one.

It is worth raising the issue of the attitude traditionally displayed by some professionals towards the choice of the method of communication for the deaf child: when considering and discussing the choice of means of communication for the child, they often suggest that their choice is a final decision. Parents and professionals discern that the development towards oral communication, even in children who have initially used sign language, has been due to the change in access to information supplied by CIs and has resulted from children's changing needs and from their choices as well. As a result, implanted children go from gestures and sign language to spoken language (see Moeller, Ertmer, \& Stoel-Gammon, 2016). The studies carried out by Tait, Raeve and Nikolopoulos (2007) have pointed out that young children with CI more readily changed their communication mode from the sign to speech--the majority of those children who had received their CI within the first year of life changed their communication from the sign to speech within six months of CI activation. This fact is referred to by their parents as a communication journey (Wheeler, Archbold, Hardie, \& Watson, 2009). 
The proportion of deaf children and older students with CIs who prefer spoken language is also growing (see O'Neill, Arendt, \& Marschark, 2014). Furthermore, as noted by Wojda (2014, p. 212), "the emerging and increasing awareness among deaf Poles of the levels of language importance in Poland, consisting in attaching special significance to the spoken Polish language, even though this fact is often concealed, is a phenomenon". Therefore, the concept that all deaf children should nowadays be raised bilingually from an early age may be unrealistic and inaccessible within the existing systems, and for the ever growing group of young deaf children, it need not be necessarily introduced under any circumstances (Knoors \& Marschark, 2012, 2014). On the other hand, however, there are also cases of implanted children who develop a special way of using gestures or signs of a sign language combined with spoken language. In academic literature, this mode of communication is referred to as sign supported speech or as simultaneous communications. It should be acknowledged that $\mathrm{d} /$ Deaf communities are currently experiencing dynamic change that represents a broad range of different language experiences showing a distinctive language continuum. It comprises not only the sign but also spoken language and mixed code variants; some deaf people do sign, others do speak, while some others again use the sign and speech simultaneously and in different ways, not necessarily being aware of the type of code they are using on a daily basis (cf. Tomaszewski \& Piekot, 2015; Wojda, 2010, 2014).

However, the aforementioned cases of deaf children with HAs, a CI and an HA or with two CIs, the children whose first language is spoken language and who are able to move from the sign to speech, do not erase the traditional approach to acquisition of sign language. This is because sign language (or the aforementioned simultaneous communications, provided that the child prefers this mode of communication) remains the only path of the deaf child's development, despite the advanced CIs and HAs. Recent international studies carried out in this respect have shown a positive effect of bimodal speech-sign bilingualism on language development in implanted deaf children of Deaf parents: they consistently acquired spoken language when being raised amid the natural sign language and also when being stimulated to develop spoken language skills (Davidson, Lillo-Martin, \& Pichler, 2014; Hassanzadeh, 2012; see also de Quadros, Lillo-Martin, \& Pichler, 2016). Similar results have been found in a case study of an implanted deaf child of hearing parents, raised in bimodal speech-sign bilingualism (Rinaldi \& Caselli, 2014). Nevertheless, the results of the above studies should not be assessed substantively because the long-term effects of early acquisition of sign language on the development of language abilities on an academic level have not been examined yet; further research is needed in this respect. It is noteworthy that the number of Deaf parents who, keeping up with the changes in the language education model for deaf children, have decided to provide their children with a CI, is growing. The reason for this is that fluency in spoken language is, in their opinion, 
essential for surviving and achieving success in a country where the dominant language is that of hearing people, whereas sign language is needed for developing the community and cultural identity (Mitchiner, 2015; Mitchiner \& Sass-Lehrer, 2011).

As regards the issue of identity in young people with CIs, particularly in those of hearing parents, they perceive themselves in a more flexible way than they did in the past: they just combine both their deaf identity and hearing identity (Moog, Geers, Gustus et al., 2011). As noted by Archbold (2015, p. 38):

With modern technologies this is almost the case; profoundly deaf children who have been implanted early can experience almost total deafness and almost "normal" levels of hearing. Although we have changed dramatically the impact of hearing loss, providing much more useful hearing than in the past, we have not "cured" deafness, but we have changed its implications. Young people talk about „being deaf differently" today. They recognize that they are deaf, as they are dependent on technology to hear, but most do not relate to Deaf culture as viewed in the past.

This shows that, independently of those two cultures--that of hearing people and that of Deaf people, implanted persons of hearing families are becoming a new group that creates a new identity of "being deaf in their own way" (Ohna, 2004).

\section{Times are changing}

The traditional deaf education model stresses the causes, the time of onset and the degree of deafness in pupils with limited hearing because this translates into the degree of intensification of the rehabilitation and speech therapy activities undertaken as part of the early intervention. Potential educational failures are explained by too late provision of hearing aids or by profound hearing loss which precludes spontaneous development of speaking skills, thus contributing to the lower level of educational development. The foreign language teaching model opposed to the medical model requires us to look for neglect just there: in the disturbed process of acquiring sign language as the first language, being the result of separation of the child from language sources perceptible to them. Hearing children are continually immersed in a spoken language bath, long before they learn reading. They are surrounded by the speech sounds, paraverbalisms and other vocal messages; the reality is explained to them, named and commented on an ongoing basis, in conversational situations. All this is a process of incidental learning. Now, this phenomenon can be observed in an increasing number of children with limited hearing thanks to the modern auditory technology, early diagnosis of limited hearing and early intervention. As a result, the population of deaf and hard of hearing children is clearly becoming more diverse in linguistic terms. This 
issue is still controversial, especially to those who hold the opinion that even now, all deaf children should be prepared for bilingual education from an early age, and that their first language should be the sign and the second language-the spoken one. This position is represented by, e.g., Świdziński (2014, p.12):

Deaf people must have PJM as their first language. They must receive it before they go into the Polish language. If their parents are hearing, PJM must get to them from outside because this language will not come to them from their hearing parents. Education must be based on Polish Sign Language as the language of instruction. The second language, or Polish, must be lectured on according to the principles of foreign language teaching.

Such homogenization may, however, blur the diversity of the population of deaf children. It should be noted that arguments about the language disproportions of between spoken language and signed language in deaf education are rather harmful than helpful. The thesis that a deaf child with advanced CIs or digital HAs, supported with appropriate speech therapy, education and technology, and learning together with hearing children under integration or inclusion conditions does not need sign language, would be risky, too. Because, as predicted by Knoors and Marschark (2012, p. 300), "it is happening often enough to indicate that there will be a significant proportion of deaf children raised with spoken language who later will seek out sign language as part of their identity". The occurrence of this phenomenon is increasingly common, although it has not yet been sufficiently established or investigated.

That is why it is necessary to update language education curricula for deaf and hard of hearing children on an ongoing basis, with account taken of the constant technological, social and cultural transformations. The updates should be based on convergence toward the so-called intermediate discourse that blurs the line between the two models of deafness--the medical model (the hearing majority's spoken language) and the sociocultural one (the Deaf community's sign language). This is essential for establishing standards for educational practices that are to be favorable to d/Deaf and hard of hearing children and their families (Tomaszewski \& Moroń, 2018). Therefore, it is worth developing a flexible model of bimodal speech-sign bilingualism because it is "a remedy that can be used at the stage of early intervention in order to support families and ensure best possible long-term effects of development for deaf children in auditory-dominant society" (Tomaszewski, in press). „A carefully implemented, differentiated language policy will better meet the current wishes, strengths, and needs of deaf children and their parents" (Knoors and Marschark (2012, p. 301). In other countries, this concept is pursued by both professionals and parents--not only hearing parents but also d/Deaf parents. 


\section{Direction for further research}

We have a number of answers to the question about the language development in deaf children (with regard to signed language and spoken language) but these issues are still understudied and thus in need of further investigation. This does not mean, as written by Spencer (2016), that we have come full circle; we are on a spiral path that climbs upward and meanders amid interdisciplinary studies and cultural contexts. Therefore, we are returning now, with a bigger pool of knowledge and experience, to the questions that have been once asked.

The first of the issues relates to research methodology, particularly to the methods of measuring the phenomena that take place and have an effect on the language and cognitive development of children with CIs or advanced HAs. It is difficult to assess the scale of impact of the use of CIs on acquisition of spoken language because different studies take into account different variables (the child's age, language environment, hearing loss etiology, hearing support techniques used by the child, etc.), apply various methods (however, typically qualitative methods) and use various research tools (from in-depth interviews to questionnaires with closed-ended questions). The research eclecticism results from the rapid development of auditory technology, especially hearing implants. The technology develops in a variety of directions and that is why research results vary greatly. As noted by Marschark, Machmer and Convertino (2016), the methods used in many studies on the development of deaf children with CIs suffer from certain shortcomings: researchers often do not present the child's level of language and cognitive functioning prior to the implantation and, as a result, they incorrectly compare such cases to other deaf children without CIs. The fact is that prior to the cochlear implantation, children are subject to observation and already then, before getting an implant, they can function better than other deaf children without CIs. The same applies to groups of deaf children with or without CIs: other variables, such as age, cause of hearing loss, age of hearing loss diagnosis, grade of hearing loss, parents' hearing capability, socioeconomic status and education level, the child's cognitive abilities, possible additional disorders, language and cultural environment, accessibility of (signed or spoken) language, intensity of the contact with language, age of first use of an HA or CI, age of the child at the time of receiving early development support, type and quality of such support etc. are often ignored. Nevertheless, the additional factors related to early language acquisition by the child, mainly as part of the primary socialization, are important. These are: "parental warmth, tendency to be responsive to the child, tendency to provide language matching the child's current focus of attention and existing language skills" (Spencer, 2016 , p. 11). We should pay attention to all that when properly employing research methods to study populations of children with CIs or HAs because 
the said factors contribute to the big individual differences among such children and account for their level of cognitive and socio-emotional functioning, both of which affect in turn the process of learning (cf. Knoors \& Marschark, 2014). In summary: In future research in this field, a priority should be given to, first and foremost, the solution of the problem of variability of the previous research results just by monitoring the multiple factors accountable for the variability.

Given the paradigm changes in the education of deaf and hard of hearing children, the recognition of signed language as a natural language, the auditory technology revolution, early diagnosis of deafness and early development support, there is an increasing need to revise the bilingual teaching policy and to redefine the model of becoming and being bilingual in different stages of education. It will be very important to revisit the planning of language acquisition and the bilingualism policy because, as a result, deaf children will gain access to the diverse language environment, also thanks to their families' support. In the last few years, differentiated forms of language environment were introduced in different deaf schools, starting from differentiating class languages, then differentiating between class groups, and finally differentiating by creating additional educational provisions, e.g., as part of cooperation with another school (Knoors \& Marschark, 2012). Similar practices are employed in the Warsaw Institute for the Deaf (see Adamiec, 2015). These changes reflect the following important fact: sign language and spoken language are now acquired in any order, depending on the varying cognitive and language abilities of deaf children as well as on the environment they are raised in. Therefore, it is necessary to undertake long-term studies to investigate the development of deaf children raised under different conditions of language stimulation in the context of bimodal bilingual education, with account taken of the variety of time orders of language acquisition. The studies should be made just now as we deal with a growing population of deaf children with CIs or HAs who can communicate in spoken language (not to mention the written form of that language) and not in sign language only. It should be taken into account that the aforementioned studies on this subject have accounted for rather relatively short-term and repeated tests with limited scopes. It is essential to examine the long-term impact of bimodal bilingualism on the wider language and cognitive functioning of children with CIs or HAs in the real world (for instance, on account of the occurrence of communication noise or articulatory assimilation in live speech). When verifying future results of such research, one could, at the same time, verify the view that it is effective communication and, hence, early and effective access to language, regardless of its variant or modality, that is one of the major factors determining school achievements at a later age (Marschark et al., 2016; Paul, 2011).

In this regard, we have to know more about deaf literacy which, in its traditional sense, refers to the reading, writing and counting skills. In its 
broader sense, literacy also covers other basic cognitive competencies, like information processing, knowledge acquisition, communication and functioning in a given culture and technology system. Although many skills and experiences of pupils help them acquire the reading and writing skills, two of them are of special importance: the speaking (articulating) skill and the skill in decoding the meanings of written words of a spoken language. The existing research on deaf literacy indicates poor literacy skills (da Fonseca Flores, \& Rumjanek, 2015; Lederberg, Spencer, \& Schick, 2013; Spencer \& Marschark, 2010). Notwithstanding the fact that the auditory technology development ensures a growing number of children greater and greater access to sound information at earlier age, the reading and writing skills still represent a considerable challenge for deaf children (Easterbrooks \& Trussell, 2016). Although, as mentioned above, there are data indicating that CIs have significantly improved the spoken language of many children with severe to profound hearing loss, their impact on literacy has proved to be considerably less consistent (see Harris, 2016). Moreover, it has even been noticed that, if there are any benefits from early reading by children with CIs, they vanish with age (Marschark, Shaver, Nagle et al., 2015). There is hence a need for research oriented at effective methods of teaching deaf pupils the reading and writing skills outside the pre-school period so that we can have in the future sufficient evidence-based practices to help teachers and parents move their children forward in acquiring literacy.

Despite the considerable progress in the recent decades due to the introduction of increasingly advanced digital HAs and to early cochlear implantation, there is still high variability in results of studies on learning spoken language by deaf children. This fact suggests that it is necessary to approach children with CIs or HAs with such flexibility as to be able to effectively recognize the language modality preferred by them in terms of the multidimensional continuum from the visual dimension through the visual-auditory dimension to the auditory one, as well as the children's preferred forms of communication, both the receptive and the expressive ones. This is essential for ensuring long-term quality and dynamic diagnosis of the development of language (sign language or spoken language) in deaf children. In such a case, it is necessary to have tools for evaluation of the development in deaf children with CIs/HAs. Admittedly, a number of tests measuring deaf children's skills in using sign language have been developed to date (see Morford, Nicodemus, \& Wilkinson, 2015) but the standardization of those tools remains the greatest challenge, given the fact that the population of deaf people is not large, and that, in addition, it is heterogeneous in terms of language (Mann \& Haug, 2016). That is not the only problem that afflicts our country. We still lack tools and methods for testing language competence of sign language users. Nevertheless, learning the principles of the testing methods developed in other countries (e.g., in the USA or the UK) may help us 
by indicating the right direction for development and creation of similar methods, adjusted to the study of Polish Sign Language. Clearly, one has to bear in mind the importance of the choice of the methodological material for the study. On account of the many differences between the modality and specificity of the signed and spoken languages, the material may not be directly transposed from the spoken language tests on the signed language tests, even if the methodology of foreign language teaching is followed. It is extremely important to appropriately design the tasks and questions that are to serve as sign language evaluation tools based on the visual modality. Whereas, for bimodal speech-sign bilingualism that is currently applied in education of a certain group of deaf children with CIs or HAs, it is necessary to develop a speech test that could be based on the tools designed for hearing children, e.g., the Communicative Development Inventory (CDI; Smoczyńska, Krajewski, Łuniewska, Haman, Bulkowski, \& Kochańska, 2015). With such "bilingual" tools for evaluation of the deaf child's developmental profile, the monitoring of bimodal acquisition of two languages by the child would allow us to establish whether the child is or not on the typical development trajectory, and, if necessary (in the case of developmental retardation), to plan early intervention. Currently, some researchers are making their way in that direction on the basis of their observation of the impact of bimodal bilingualism on language development in hearing children of deaf parents (see de Quadros, Pichler, \& Lillo-Martin, 2015; de Quadros, Lillo-Martin, \& Pichler, 2016). This is relevant for two reasons. The first reason is that the majority of deaf children of hearing parents who, as reported by Mitchell and Karchmer (2011), make up $95 \%$ of the population of deaf children, may be at risk, not of sensory deprivation (including auditory deprivation) but, first and foremost, of language deprivation in the context of limited access to the full language resources (see Hall, 2017; Hall, Eigsti, Bortfeld et al., 2016; Tomaszewski, in press). The second reason is that among deaf and hard of hearing people, just as among hearing people using spoken language, there are also cases of specific language impairment affecting those people's use of sign language (Morgan, Herman, \& Woll, 2007; Marshall \& Morgan, 2016; Mason, Rowley, Marshall et al., 2010).

The availability of a basic tool for the assessment and evaluation of the needs of deaf children in different stages of their language development is also essential for future research on their cognitive functioning, especially if they are bimodally exposed to two languages--the spoken language and the sign, since, on the one hand, a considerable amount of data suggest that acquisition of two languages--in the unimodal context ${ }^{7}$--can lead to cognitive advantages, thus strengthening such components of the executive functioning as attention, inhibition, switching between tasks and working memory (Bialystok \& Craik, 2010). But on the other hand, we do not know whether those

\footnotetext{
7 Individuals fluent in two spoken languages.
} 
conditions also occur in the case of bimodal bilingualism, since, as Ormel and Giezen (2014) wrote, its implications for the cognitive effects are still unclear. Still, other researchers, e.g., Emmorey, Giezen and Gollan (2016) believe that the sustained controlling of two languages from differing modalities in bimodal bilinguals may lead to modality-specific cognitive advantages in contrast to unimodal bilinguals. Hence, if those conditions do exist, they must first be identified in further research.

In the socio-cognitive context, too, it would be useful to carry out a more detailed study on children with CIs or HAs raised under different language stimulation conditions to investigate the impact of their command of language(s) on the development of the theory of mind (ToM). Recent studies have shown that despite the progress that has been made possible through hearing technology, hearing screening, early-development support, deaf and hearing children still may differ in their social-cognitive development, because differences in the language quality are provided by their (hearing) parents (see Morgan, Meristo, \& Mann, 2014). Previous studies have also highlighted the importance of the quality of language input in the educational environment: It was observed that deaf children of deaf parents who implemented the bilingual/bimodal programs had ToM skills similar to hearing peers, but deaf children of deaf parents who were in oral programs showed delays in ToM (Meristo, Falkman, Hielmguist et.al., 2007).

To sum up the issues of language and cognitive development in deaf children: The most important issue remains the effective immersion of the child in the language bath allowing the child to acquire language, preferably as an incidentally developed code. It is relevant whether the more perceptible language will be spoken language or signed language. In this regard it should be noted that language multimodality (gestures, signs, spoken words, writing) makes a significant contribution to the development of language creativity in the deaf child which can manifest itself when the child is actively and incidentally learning how to communicate with others. That is necessary to ensure that deaf children--just as hearing children--have a status, as figuratively highlighted by Bokus and Shugar (2007, p. 27), of a "child as a psychologist" so that they can properly interpret others' intentions in communication situations, and of a "child as a language builder" so that they can consistently pick up the language patterns they hear and see in other people's utterances and, on this basis, spontaneously build up their own language system.

\section{Acknowledgments}

This paper was supported by the Principal Research Fund of the Faculty of Psychology, University of Warsaw (BST 181437/2017, BST 186800-43/2018). 


\section{References}

Adamiec, T. (2015). Analiza modelu edukacji dwujęzycznej dzieci głuchych [Analysis of the model of bilingual education for deaf children]. Unpublished manuscript, Instytut Głuchoniemych, Warszawa.

Archbold, S. (2015). Being a deaf student: Changes in characteristics and needs. In H. Knoors \& M. Marschark (Eds.), Educating deaf learners: Creating a global evidence base (pp. 23-46). New York, NY: Oxford University Press.

Barker, D. H., Quittner, A. L., Fink, N. E., Eisenberg, L. S., Tobey, E. A., \& Niparko, J. K. (2009). Predicting behavior problems in deaf and hearing children: The influences of language, attention, and parent-child communication. Development and Psychopathology, 21(2), 373-392.

Barnard, J. M., Fisher, L. M., Johnson, K. C., Eisenberg, L. S., Wang, N. Y., \& Quittner, A. L., and the CDaCI Investigative Team (2015). A prospective, longitudinal study of US children unable to achieve open-set speech recognition five years after cochlear implantation. Otology and Neurology, 36(6), 985-992.

Bialystok, E. \& Craik, F. I. (2010). Cognitive and linguistic processing in the bilingual mind. Current Directions in Psychological Science, 19(1), 19-23.

Bokus, B. (1991). Tworzenie opowiadań przez dzieci. O linii i polu narracji [Children building stories. Narrative line and narrative field]. Kielce: Energeia.

Bokus, B. \& Shugar, G.W. (1995). Analiza tekstu tworzonego przez dziecko w dyskursie narracyjnym (Wybór treści znanych i nie znanych odbiorcy). [Analysis of text created by children in narrative discourse (Choice of content known or unknown to the listener)]. In G.W. Shugar (Ed.), Dyskurs dziecięcy. Rozwój w ramach struktur społecznych [Child discourse. Development in the framework of social structures] (pp. 105-118). Warszawa: Energeia.

Bokus, B. \& Shugar, G.W. (1998). Social structures of children's narrational activity. Psychology of Language and Communication, 2(1), 75-81.

Bokus, B. \& Shugar, G. W. (2007). Psychologia języka dziecka: stare pytania, nowe dane, nowe hipotezy [Psychology of child language: old questions, new data, and new hypotheses]. In B. Bokus, G.W. Shugar (Eds.), Psychologia języka dziecka. Osiagnięcia, nowe perspektywy [Psychology of child language. Achievements and new prospects] (pp. 9-32). Gdańsk: Gdańskie Wydawnictwo Psychologiczne.

Boyes Braem, P. \& Rathmann, Ch. (2010). Transmission of sign languages in Northern Europe. W: D. Brentari (Ed.), Sign Languages: Cambridge Language Survey (pp. 19-45). Cambridge, UK: Cambridge University Press.

Brentari, D. (Ed.). (2010). Sign Languages. Cambridge, UK: Cambridge University Press.

Chamberlain, C., Morford, J. P., \& Mayberry, R. I. (Eds.). (2000). Language Acquisition by Eye. Mahwah, NJ: Lawrence Erlbaum Associates. 
Christiansen, J. B. (2014). Fifteen cochlear implant stories. Journal of Deaf Studies and Deaf Education, 19(4), 560.

Davidson, K., Lillo-Martin, D., \& Chen Pichler, D. (2014). Spoken English language development among native signing children with cochlear implants. Journal of Deaf Studies and Deaf Education, 19(2), 238-250.

da Fonseca Flores, A. \& Rumjanek, V. (2015). Teaching science to elementary school deaf children in Brazil. Creative Education, 6, 2127-2135.

Day, P. S. (1986). Deaf children's expression of communicative intentions. Journal of Communication Disorders, 19(5), 367-385.

Dziemidowicz, Cz. (1996). Dziecko gluche i język ojczysty [Deaf child and the mother tongue]. Bydgoszcz: Tanan.

Emmorey, K. (2002). Language, Cognition, and the Brain: Insights From Sign Language Research. Mahwah, NJ: Erlbaum.

Emmorey, K. (2011). The neural systems underlying sign language. In M. Marschark \& P. E. Spencer (Eds.), The Oxford Handbook of Deaf Studies, Language, and Education. Volume 1. Second Edition (pp. 380-398). New York, NY: Oxford University Press.

Emmorey, K., Giezen, M. R., \& Gollan, T. H. (2016). Psycholinguistic, cognitive, and neural implicaions of bimodal bilingualism. Bilingualism: Language and Cognition, 19(2), 223-242.

Easterbrooks, S. R., \& Trussell, J. W. (2016). Encouraging emergent reading in deaf and hard of hearing children. In M. Marschark \& P. E. Spencer (Eds.), The Oxford Handbook of Deaf Studies in Language (pp. 377-392). New York, NY: Oxford University Press.

Farris, M. A. (1994). Sign language research and Polish Sign Language. Lingua Posnaniensis, 36, 13-36.

Franz, D. C., Caleffe-Schenck, N., \& Kirk, K. I. (2000). A tool for assessing functional use of audition in children: Results in children with the MED-EL COMBI 40 cochlear implant system. The Volta Review, 104(3), 175-196.

Gee, J. P., \& Googhart, W. (1988). American Sign Language and the human biological capacity for language. In M. Strong (Ed.), Language Learning and Deafness (pp. 49-74). New York and Cambridge, UK: Cambridge University Press.

Gee, J. P., \& Mounty, J. L. (1991). Nativization, variability, and style shifting in the sign language development of deaf children of hearing parents. In P. Siple \& S. Fischer (Eds.), Theoretical Issues in Sign Language Research, Vol. 2: Psychology (pp. 65-83). Chicago, IL: University of Chicago Press.

Goldin-Meadow, S. (2003). The Resilience of Language. New York, NY: Psychology Press.

Greenberg, M. T. (1980). Social interaction between deaf preschoolers and their mothers: The effects of communication method and communication competence. Developmental Psychology, 16(5), 465-474. 
Gregory, S., \& Bishop, J. (1982). The language development of deaf children during their first term at school. Paper presented at the Child Language Seminar, Birkbeck College. London.

Grosjean, F. (2001). The right of the deaf child to grow up bilingual. Sign Language Studies, 1(2), 110-114.

Hall, M., Eigsti, I. M., Bortfeld, H., \& Lillo-Martin, D. (2016). Auditory deprivation does not impair executive function, but language deprivation might: Evidence from a parent-report measure in deaf native signing children. Journal of Deaf Studies and Deaf Education, 22(1), 9-21.

Hall, W. C. (2017). What you don't know can hurt you: The risk of language deprivation by impairing sign language development in deaf children. Maternal and Child Health Journal, 21(5), 961-965.

Hall, W. C., Levin, L. L., Anderson, M. L. (2017). Language deprivation syndrome: a possible neurodevelopmental disorder with sociocultural origins. Social Psychiatry and Psychiatric Epidemiology, 52(6), 761-776.

Harris, M. (2016). The impact of cochlear implants on deaf children's literacy. In M. Marschark \& P. E. Spencer (Eds.), The Oxford Handbook of Deaf Studies in Language (pp. 407-419). New York, NY: Oxford University Press.

Hassanzadeh, S. (2012). Outcomes of cochlear implantation in deaf children of deaf parents: Comparative study. Journal of Laryngology and Otology, 126(10), 989-994.

Helmuth, L. (2001). From the mouths (and hands) of babes. Science, 293, $1758-1759$.

Hodgson, K. W. (1953). The Deaf and their Problems: A Study in Special Education. London: C.A. Watts and Company, Ltd.

Hoffmeister, R. (2000). A piece of the puzzle: ASL and reading comprehension in deaf children. In C. Chamberlain, J. Morford, \& R. Mayberry (Eds.), Language Acquisition by Eye (pp. 143-163). Mahwah, NJ: Lawrence Erlbaum Associates.

Houston, D. M., Carter, A. K., Pisoni, D. B., Kirk, K. J., \& Ying, E. A. (2005). Word learning in children following cochlear implantation. The Volta Review, 105(1), 41-72.

Humphries, T., Kushalnagar, P. , Mathur, G., Napoli, D. J., Padden, C., Rathmann, Ch., \& Smith, S. (2012). Cochlear implants and the right to language: Ethical considerations, the ideal situation, and practical measures toward reaching the ideal. In C. Umat \& R. A. Tange (Eds.), Cochlear Implant Research Updates (pp.193-212). Shanghai: InTech.

Humphries, T., Kushalnagar, P., Mathur, G., Napoli, D. J., Padden, C., Rathmann, Ch., \& Smith, S. (2016a). Avoiding linguistic neglect of deaf children. Social Service Review, 90(4), 589-619. 
Humphries, T., Kushalnagar, P., Mathur, G., Napoli, D. J., Padden, C., Rathmann, Ch., \& Smith, S. (2016b). Language choices for deaf infants. Advice for parents regarding sign languages. Clinical Pediatrics, 55(6), 513-517.

Humphries, T., Kushalnagar, P., Mathur, G., Napoli, D. J., Padden, C., Rathmann, Ch., \& Smith, S. (2017). Discourses of prejudice in the professions: the case of sign languages. Journal of Medical Ethics, 43(9), 1-5.

Jackendoff, R. (1999). Possible stages in the evolution of the language capacity. Trends in Cognitive Sciences, 3(7), 272-279.

Johnson, R., Liddell, S., \& Erting, C. (1989). Unlocking the Curriculum Principles for Achieving Access in Deaf Education. Washington, DC: Gallaudet University, Gallaudet Research Institute.

Kegl, J. (1994). The Nicaraguan Sign Language project: An overview. Signpost, 7, 24-31.

Kegl, J., Senghas A., Coppola M. (1999). Creation through contact: Sign language emergence and sign language change in Nicaragua. In M. DeGraff (Eds.), Language creation and language change: Creolization, diachrony, and development (pp.179-238). Cambridge, MA: MIT Press.

Knoors, H. \& Marschark, M. (2012). Language planning for the 21st century: Revisiting bilingual language policy for deaf children. Journal of Deaf Studies and Deaf Education, 17(3), 291-305.

Knoors, H. \& Marschark, M. (2014). Teaching Deaf Learners. Psychological and Developmental Foundations. New York, NY: Oxford University Press.

Knoors, H., Tang, G., \& Marschark, M. (2014). Bilingualism and bilingual deaf education. In M. Marschark, G. Tang, \& H. Knoors (Eds.), Bilingualism and Bilingual Deaf Education (pp.1-20). New York, NY: Oxford University Press.

Krakowiak, K. (1995). Fonogesty jako narzędzie formowania języka dzieci z uszkodzonym stuchem. Komunikacja językowa i jej zaburzenia [Cued Speech as a tool for language formation in children with hearing impairment. Linguistic communication and its disorders]. Lublin: Wydawnictwo UMCS. Krzysztofiak, P. (2017). Rozwój językowy u uczniów głuchych a hipoteza okresu krytycznego [Language development in deaf learners and the critical period hypothesis] (Unpublished Master's Thesis). Faculty of Psychology, SWPS University of Social Sciences and Humanities, Warsaw, Poland.

Lederberg, A. R., \& Everhart, V. S. (1998). Communication between deaf children and their hearing mothers: The role of language, gesture, and vocalizations. Journal of Speech and Hearing Research, 41(4), 887-899.

Lederberg, A. R., \& Everhart, V. S. (2000). Conversations between deaf children and their hearing mothers: Pragmatic and dialogic characteristics. Journal of Deaf Studies and Deaf Education, 5(4), 303-322.

Lederberg, A. R., Schick, B., \& Spencer, P. E. (2013). Language and literacy development of deaf and hard-of-hearing children: Successes and challenges. Developmental Psychology, 49(1), 15-30. 
Leigh, I. W., \& Christiansen J. B. (2003). Cochlear Implants in Children: Ethics and Choices. In D. Nussbaum, R. LaPorta, and J. Hinger (Eds.), Cochlear implants and sign language: Putting it all together (pp. 9-15). Washington, D.C.: Laurent Clerc National Deaf Education Center Gallaudet University.

Leigh, I. W., \& Andrews, J. F. (2017). Deaf People and Society. Psychological, Sociological and Educational Perspectives. Second Edition. New York, NY: Routledge.

Lenihan, S. (2010). Trends and challenges in teacher preparation in deaf education. The Volta Review, 110(2), 117-128.

Litovsky, R. Y., Johnstone, P. M., Godar, S., Agrawal, S., Parkinson, A., Peters, R., \& Lake, J. (2006). Bilateral Cochlear Implants in Children: Localization Acuity Measured with Minimum Audible Angle. Ear and Hearing, 27(1), 43-59.

Łozińska, S., Rutkowski, P. (2017). Język migowy źródłem pamięci społecznej Głuchych [Sign language as a source of the social memory of the Deaf]. Horyzonty Wychowania, 16(38), 91-108.

Majewska, M. (2016). Okres krytyczny w rozwoju języka a przyswajanie polskiego języka migowego przez osoby głuche wychowywane w różnych warunkach stymulacji językowej [The critical period in Polish Sign Language acquisition for deaf people raised in different linguistic stimulation conditions] (Unpublished Master's Thesis). Faculty of Psychology, University of Warsaw, Poland.

Mann, W., \& Haug, T. (2016). New directions in signed language assessment. In M. Marschark \& P. E. Spencer (Eds.), The Oxford Handbook of Deaf Studies in Language (pp. 299-310). New York: Oxford University Press.

Marschark, M. (2007). Raising and Educating a Deaf Child: A Comprehensive Guide to the Choices, Controversies, and Decisions Faced by Parents and Educators. New York, NY: Oxford University Press.

Marschark, M., \& Hauser P. C. (2012). How Deaf Children Learn. What Parents and Teachers Need to Know. New York, NY: Oxford University Press.

Marschark, M., Machmer, E., \& Convertino, C. (2016). Understanding language in the real world. In M. Marschark, P. E. Spencer (Eds.), The Oxford Handbook of Deaf Studies in Language (pp. 431-451). New York, NY: Oxford University Press.

Marschark, M., Tang, G., \& Knoors, H. (Eds.). (2014). Bilingualism and Bilingual Deaf Education. New York, NY: Oxford University Press.

Marschark, M., Shaver, D. M., Nagle, K. M., \& Newman, L. A. (2015). Predicting the academic achievement of deaf and hard-of-hearing students from individual, household, communication, and educational factors. Exceptional Children, 81(3), 350-369. 
Marschark, M. \& Wauters, L. (2011). Cognitive functioning in deaf adults and children. In M. Marschark \& P. E. Spencer (Eds.), The Oxford Handbook of Deaf Studies, Language, and Education. Volume 1. Second Edition (pp. 486-499). New York, NY: Oxford University Press.

Marshall, C. \& Morgan, G. (2016). Investigating sign language development, delay, and disorder in deaf children. In M. Marschark, \& P. E. Spencer (Eds.), The Oxford Handbook of Deaf Studies in Language (pp. 311-324). New York, NY: Oxford University Press.

Mason, K., Rowley, K., Marshall, C. R., Atkinson, J. R., Herman, R., Woll, B., \& Morgan, G. (2010). Identifying SLI in Deaf children acquiring British Sign Language: Implications for theory and practice. British Journal of Developmental Psychology, 28(1), 33-49.

Mayberry, R. (1994). The importance of childhood to language acquisition: Insights from American Sign Language. In J.C. Goodman \& H.C. Nusbaum (Eds.), The Development of Speech Perception: The Transition from Speech Sounds to Words (pp. 57-90). Cambridge, MA: MIT Press.

Mayberry, R. (1995). Mental phonology and language comprehension or What does that sign mistake mean? In K. Emmorey, \& J. Reilly (Eds.), Language, Gesture, and Space (pp. 355-370). Hillsdale, NJ: Lawrence Erlbaum Associates.

Mayberry, R. I. (2010). Early Language acquisition and adult language ability. What sign language reveals about the critical period for language. In M. Marschark, \& P. E. Spencer (Eds.), The Oxford Handbook of Deaf Studies, Language, and Education. Volume 2 (pp. 281-291). New York, NY: Oxford University Press.

Mayberry, R. \& Eichen, E. (1991). The long-lasting advantage of learning sign language in childhood: Another look at the critical period for language acquisition. Journal of Memory and Language, 30(4), 486-512.

Mayberry, R. I. \& Fischer, S. D. (1989). Looking through phonological shape to lexical meaning: The bottleneck of nonnative sign language processing. Memory and Cognition, 17(6), 740-754.

Mayer, C., \& Leigh, G. (2010). The changing context for sign bilingual education programs: Issues in language and the development of literacy. International Journal of Bilingual Education and Bilingualism, 13(2), 175-186.

Meadow, K. P. (1968). Early manual communication in relation to the deaf child's intellectual, social, and communi $\neg$ ca $\neg$ tive functioning. American Annals of the Deaf, 113(1), 29-41.

Meadow, K. P., Greenberg, M. T., Erting, C., \& Carmicheal, H. (1981). Interactions of deaf and mother and deaf preschool children: Comparisons with three other groups of deaf hearing dyads. American Annals of the Deaf, 126(4), 454-468. 
Meristo, M., Falkman, K. W., Hjelmquist, E., Tedoldi, M., Surian, L., \& Siegal, M. (2007). Language access and theory of mind reasoning: Evidence from deaf children in bilingual and oralist environments. Developmental Psychology, 43(5), 1156-1169.

Mitchell, R. E. \& Karchmer, M. A. (2011). Demographic and achievement characteristics of deaf and hard of hearing students. In M. Marschark \& P. E. Spencer (Eds.), The Oxford Handbook of Deaf Studies, Language, and Education. Volume 1. Second Edition (pp. 18-31). New York, NY: Oxford University Press.

Mitchiner, J. C. (2015). Deaf parents of cochlear-implanted children: beliefs on bimodal bilingualism. Journal of Deaf Studies and Deaf Education, 20(1), 51-66.

Mitchiner, J. C., \& Sass-Lehrer, M. (2011). My child can have more choices: Reflections of Deaf mothers on cochlear implants for their children. In R. Paludneviciene, \& I. W. Leigh (Eds.), Cochlear Implants: Evolving Perspectives (pp. 71-94). Washington, DC: Gallaudet University Press.

Moeller, M., Ertmer, D., \& Stoel-Gammon, C. (Eds.) (2016), Contemporary Methods of Promoting Speech and Language Development in Children Who Are Deaf and Hard of Hearing. Baltimore, MD: Brookes.

Montgomery, G. W. G. (1966). The relationship of oral skills to manual communication in profoundly deaf adolescents. American Annals of the Deaf, 111(4), 557-565.

Moog, J. S., Geers, A. E., Gustus, Ch., \& Brenner, Ch. (2011). Psychosocial adjustment in adolescents who have used cochlear implants since preschool. Ear and Hearing, 32(1), 75S-83S.

Morford, J. P, Nicodemus, B., \& Wilkinson, E. (2015). Research Methods in Psycholinguistic Investigations of Sign Language Processing. In E. Orfanidou, B. Woll \& G. Morgan (Eds.), Research Methods in Sign Language Studies: A Practical Guide (pp. 209-249). Chichester, West Sussex, UK: Wiley Blackwell.

Morgan G., Herman R., \& Woll B., (2007). Language impairments in sign language: Breakthroughs and puzzles. International Journal of Language and Communication Disorders, 42(1), 97-105

Morgan, G., Meristo, M., Mann, W., Hjelmquist, E., Surian, L., \& Siegal, M. (2014). Mental state language and quality of conversational experience in deaf and hearing children. Cognitive Development, 29, 41-49.

Morgan, G. \& Woll, B. (Eds.). (2002). Directions in Sign Language Acquisition. Amsterdam: John Benjamins.

Moroń E. (2014). Ideologiczny kontekst wiedzy milczącej w artykułach naukowych o głuchocie [The ideological context of silent knowledge in scientific papers on deafness]. In M. Sak (Ed.), Deaf Studies w Polsce. Tom 1 [Deaf Studies in Poland. Volume 1] (pp. 17-31). Łódź: Polski Związek Głuchych Oddział Łódzki. 
Moroń, E., \& Zarzeczny, G. (2014). Głuchy - językowe podstawy stereotypu [The Deaf: The linguistic basis for the stereotype]. In M. Sak (Ed.), Edukacja gtuchych [Deaf Education] (pp. 117-125). Warszawa: Biuro Rzecznika Praw Obywatelskich.

National Institute on Deafness and Other Communication Disorders [NIDCD] (2010). Cochlear implants. Retrieved from https://report.nih.gov/ nihfactsheets/Pdfs/CochlearImplants(NIDCD).pdf

Newport, E.L. (1990). Maturational constraints on language learning. Cognitive Science, 14(1), 11-28.

Newport, E. L. \& Meier, R. (1985). Acquisition of American Sign Language. In D. I. Slobin (Ed.), The Cross-Linguistic Study of Language Acquisition (pp. 881-938). Hillsdale, NJ: Lawrence Erlbaum Associates.

Nicholas, J. (2000). Age differences in the use of informative/heuristic communicative functions in young children with and without hearing loss who are learning spoken language. Journal of Speech Language and Hearing Research, 43(2), 380-394.

Nicholas, J. G., \& Geers, A. E. (2003). Personal, social, and family adjustment in school-aged children with a cochlear implant. Ear and Hearing, 24(1), 69S-81S.

Niparko, J. K., Tobey, E. A., Thal, D. J., Eisenberg, L. S., Wang, N.Y., Quittner, A. L., Fink, N. E., and Investigative Team (2010). Spoken language development in children following cochlear implantation. Journal of the American Medical Association, 303(15), 1498-1506.

Nussbaum, D. B., Scott, S., \& Simms, L. E. (2012). The "Why" and "How" of an ASL/English Bimodal Bilingual Program. Odyssey, 13, 14-19.

Ohna, S. (2004). Deaf in my own way: Identity, learning and narrative. Deafness and Education International, 6(1), 20-38.

Ormel, E., \& Giezen, M. (2014). Bimodal bilingual cross-language interaction; pieces of the puzzle. In M. Marschark, G. Tang, \& H. Knoors (Eds.). Bilingualism and Bilingual Deaf Education (pp. 74-101). New York, NY: Oxford University Press.

O'Neill, R., Arendt, J., \& Marschark, M. (2014). Report from the achievement and opportunities for deaf students in the United Kingdom: From research to practice project. University of Edinburgh.

Padden, C., \& Ramsey, C. (2000). American Sign Language and reading ability in deaf children. In C. Chamberlain, J. P. Morford, \& R. I. Mayberry (Eds.), Language Acquisition by Eye (pp. 165-189). Mahwah, NJ: Lawrence Erlbaum Associates.

Paludneviciene, R., \& Leigh, I. W. (2011). Introduction. In R. Paludneviciene \& I. W. Leigh (Eds.), Cochlear Implants: Evolving Perspectives (pp. VII-XI). Washington, DC: Gallaudet University Press. 
Paul, P. (2011). A perspective on language and literacy issues. In D. Moores (Ed.), Partners in education: Issues and trends from the 21st International Congress on the Education of the Deaf (pp. 51-61). Washington, DC: Gallaudet University Press.

Pfau, R., Steinbach, M., \& Woll, B. (Eds.) (2012). Sign Language. An International Handbook. Berlin: De Gruyter Mouton.

Podgórska-Jachnik, D. (2013). Glusi. Emancypacje [Deaf emancipation]. Łódź: Wydawnictwo Naukowe Wyższej Szkoły Pedagogicznej.

Poizner, H., Klima, E., \& Bellugi, U. (1987). What the Hands Reveal About the Brain. Cambridge, MA: MIT Press.

Potrzebka, W., Moroń, E., Tomaszewski, P., \& Piekot, T. (2015). Implantacja ślimakowa z perspektywy krytycznej [Cochlear implantation from a critical perspective]. In K. Bargiel-Matusiewicz, P. Tomaszewski, , \& E. Pisula, (Eds.), Kulturowe oraz społeczne aspekty zdrowia i obrazu ciała [Cultural and social aspects of health and body image] (pp. 67-87). Warszawa: Wydawnictwo UW.

Prinz, P. M. \& Prinz, E. A. (1985). If only you could hear what I see: Discourse development in sign language. Discourse Processes, 8(1), 1-19.

Prinz, P., \& Strong, M. (1998). ASL proficiency and English literacy within a bilingual deaf education model of instruction. Topics in Language Disorders, 18(4), 47-60.

Quadros, R. M. de, Lillo-Martin, D., \& Chen Pichler, D. (2016). Bimodal bilingualism. Sign language and spoken language. In M. Marschark, \& P. E. Spencer (Eds.), The Oxford Handbook of Deaf Studies in Language (pp. 181-196). New York, NY: Oxford University Press.

Quadros, R. M., de, Chen Pichler, D., Lillo-Martin, D., Cruz, C. R., Kozak, L. V., Palmer, J. L., Pizzio, A. L., \& Reynolds, W. (2015). Methods in bimodal bilingualism research: Experimental studies. In E. Orfanidou, B. Woll \& G. Morgan (Eds.), Research Methods in Sign Language Studies: A Practical Guide (pp. 250-280). Chichester, West Sussex, UK: Wiley Blackwell.

Rinaldi, P., Caselli, M. C., (2014). Language development in a bimodal bilingual child with cochlear implant: A longitudinal study. Bilingualism: Language and Cognition, 17(4), 798-809.

Rutkowski, P. \& Łozińska, S. (Eds.). (2014). Lingwistyka przestrzeni i ruchu. Komunikacja migowa a metody korpusowe [Linguistics of space and movement. Sign language communication and corpus methods]. Warszawa: Wydział Polonistyki Uniwersytetu Warszawskiego

Rutkowski, P. \& Łozińska, S. (2016). Argument linearization in a threedimensional grammar: A typological perspective on word order in Polish Sign Language (PJM). Journal of Universal Language, 17(1), 109-134.

Sak, M. (2014). Deaf Studies w Polsce [Deaf Studies in Poland]. In M. Sak (Ed.), Deaf Studies w Polsce. Tom 1 [Deaf Studies in Poland. Volume 1] (pp. 7-16). Łódź: Polski Związek Głuchych Oddział Łódzki. 
Schick, B., Marschark, M., \& Spencer, P. E. (Eds.). (2006). Advances in the Sign Language Development of Deaf Children. New York, NY: Oxford University Press.

Schirmer, B. R. (2001). Psychological, Social, and Educational Dimensions of Deafness. Boston, MA: Allyn \& Bacon.

Schlesinger H. S., \& Meadow K. P. (1972). Sound and sign: Childhood Deafness and Mental Health. Berkeley, CA: University of California Press.

Senghas, A. (1995). Children's contribution to the birth of Nicaraguan Sign Language. Unpublished doctoral dissertation, Massachusetts Institute of Technology, Cambridge, MA.

Senghas, A. (2005). Language Emergence: Clues from a New Bedouin Sign Language. Current Biology, 15(12), R463-R465.

Senghas A., Coppola, M. (2001). Children creating language: How Nicaraguan Sign Language acquired a spatial grammar. Psychological Science, 12(4), 323-328.

Smoczyńska, M., Krajewski, G., Łuniewska, M., Haman, E., Bulkowski, K., \& Kochańska, M. (2015). Inwentarze rozwoju mowy i komunikacji (IRMIK): Stowa i Gesty, Stowa i Zdania: Podręcznik [Communicative development inventory (CDI): Words and gestures, words and sentences: Manual] Warsaw: Instytut Badań Edukacyjnych.

Spencer, P. E. (2016). It seems like only yesterday... In M. Marschark \& P. E.

Spencer (Eds.), The Oxford Handbook of Deaf Studies in Language (pp. 3-18). New York, NY: Oxford University Press.

Spencer, P. E., \& Koester, L. S. (2016). Nurturing Language and Learning. Development of Deaf and Hard-of-Hearing Infants and Toddlers. New York, NY: Oxford University Press.

Spencer, P. E., \& Marschark, M. (2003). Cochlear implants: Issues and implications. In M. Marschark, \& P. E. Spencer (Eds.), Oxford Handbook of Deaf Studies, Language and Education (pp. 434-448). New York, NY: Oxford University Press.

Spencer, P. E., \& Marschark, M. (2010). Evidence-Based Practice in Educating Deaf and Hard of Hearing Students. New York, NY: Oxford University Press. Stewart, D., \& Clarke, B. (2003). Literacy and Your Deaf Child: What Every Parent Should Know. Washington, DC: Gallaudet University Press.

Stokoe, W. C. (1960). Sign language structure: an outline of the visual communication systems of the American Deaf. New York, NY: University of Buffalo Press.

Strong, M., \& Prinz, P. (1997). A study of the relationship between ASL and English literacy. Journal of Deaf Studies and Deaf Education, 2(1), 37-46.

Strong, M., \& Prinz, P. M. (2000). Is American Sign Language skill related to English literacy? In C. Chamberlain, J. Morford, \& R. Mayberry (Eds.), Language Acquisition by Eye (pp. 131-141). Mahwah, NJ: Lawrence Erlbaum Associates. 
Stuckless, E. R., \& Birch, J. W. (1966). The influence of early manual communication on the linguistic development of deaf children. American Annals of the Deaf, 111(2), 452-460.

Supalla, S. J. (1991). Manually Coded English: The modality question in signed language development In P. Siple \& S. D. Fischer (Eds.), Theoretical Issues in Sign Language Research: Volume 2. Psychology (pp. 85-109). Chicago, IL: University of Chicago Press.

Świdziński, M. (2014). Wprowadzenie [Introduction]. In M. Świdziński (Ed.), Sytuacja osób głuchych w Polsce. Raport zespotu ds. g/Gluchych przy Rzeczniku Praw Obywatelskich [The situation of deaf people in Poland. The report of the d/Deaf Comimitte of the Commisioner for Human Rights] (pp. 8-12). Warszawa: Biuro Rzecznika Praw Obywatelskich.

Świdziński, M., \& Gałkowski, T. (Eds.). (2003). Studia nad kompetencja językowa $i$ komunikacja niestyszacych [Studies on linguistic competence and communication in deaf people]. Warszawa: Uniwersytet Warszawski, Polski Komitet Audiofonologii, Instytut Głuchoniemych im. ks. Jakuba Falkowskiego.

Tait, M., Raeve, L. de, \& Nikolopoulos, T. P. (2007). Deaf children with cochlear implants before the age of 1 year: Comparison of preverbal communication with normally hearing children. International Journal of Pediatric Otorhinolaryngology, 71(10), 1605-1611.

Tarwacka-Odolczyk, A., Tomaszewski, P., Szymańska, A., \& Bokus, B. (2014). Deaf children building narrative texts. Effect of adult-shared vs. non-shared perception of a picture story. Psychology of Language and Communication, 18(2), 149-177.

Tenenbaum, D. (2011). Deaf children: Study shows significant language progress after two cochlear implants. Retrieved October 21, 2017, from https://news. wisc.edu/deaf-children-study-shows-significant-language-progress-aftertwo-cochlear-implants/

Tomaszewski, P. (2000). Rozwój językowy dziecka głuchego: wnioski dla edukacji szkolnej [Language development of the deaf child: Implications for education]. Audiofonologia, 16, 51-85.

Tomaszewski, P. (2001). Sign language development in young deaf children, Psychology of Language and Communication, 5(1), 67-80.

Tomaszewski, P. (2003a) Przyswajanie języka migowego przez dziecko głuche rodziców głuchych [The acquisition of sign language by deaf children of deaf parents]. Przeglad Psychologiczny, 46(1), 101-128.

Tomaszewski, P. (2003b). Formalna i funkcjonalna analiza zachowań językowych i niewerbalnych dziecka głuchego: Studium psycholingwistyczne [Formal and functional analysis of linguistic and nonverbal behaviors of the deaf child: A psycholinguistic study] (Unpublished doctoral dissertation). Institute of Psychology, Polish Academy of Sciences, Warsaw, Poland. 
Tomaszewski, P. (2006). Przyswajanie języka migowego przez dzieci głuche w różnych warunkach stymulacji językowej [The acquisition of sign language by deaf children at differential conditions of linguistic stimulation]. In: T. Gałkowski \& E. Pisula (Eds.). Psychologia rehabilitacyjna - wybrane zagadnienia [Rehabilitation psychology - selected issues] (pp.83-110). Warszawa: Instytut Psychologii PAN.

Tomaszewski, P. (2008a). Child visual discourse: The use of language, gestures, and vocalizations by deaf preschoolers. Polish Psychological Bulletin, 39(1), 9-18.

Tomaszewski, P. (2008b). Interactions of deaf preschoolers: a comparison of the communicative behaviors of deaf children of deaf parents and of deaf children of hearing parents. Psychology of Language and Communication, 12(2), 69-87.

Tomaszewski, P. (2010). Fonologia wizualna polskiego języka migowego [Visual Phonology of Polish Sign Language]. Warszawa: Matrix.

Tomaszewski, P.(2011).Lingwistyczny opis struktury polskiegojęzyka migowego [Linguistic description of dtructure Polish Sign Language]. In I. Kurcz \& H. Okuniewska (Eds.), Język jako przedmiot badań psychologicznych, Tom 1: Psycholingwistyka ogólna i neurolingwistyka [Language as the object of psychological research. Vol.1: Psycholinguistics and Neurolinguistics] (pp. 184-238). Warszawa: Wydawnictwo SWPS Academica.

Tomaszewski, P. (2015a). Constraints on negative prefixation in Polish Sign Language. PLoS ONE, 10(11): e0143574. doi:10.1371/journal.pone.0143574

Tomaszewski, P. (2015b). Rozwijanie kompetencji socjokulturowej w nauczaniu polskiego języka migowego [Sociocultural competence development in teaching of Polish Sign Language]. W: P. Tomaszewski, K. BargielMatusiewicz, \& E. Pisula (Eds.), Spoteczne i kulturowe aspekty zdrowia $i$ niepetnosprawności [Social and cultural aspects of health and disability] (pp. 21-40). Warszawa: Wydawnictwo Uniwersytetu Warszawskiego.

Tomaszewski, P. (in press). Implanty ślimakowe - etyka a wybór [Cochlear implants - ethics and choice]. Kultura-Społeczeństwo-Edukacja.

Tomaszewski, P. \& Bandurski, M. (2007). Rozwój językowy i poznawczy dzieci głuchych a strategie wychowawcze ich rodziców [Language and cognitive development in deaf children and parenting strategies]. In E. Pisula \& D. Danielewicz (Eds.), Rodzina z dzieckiem niepetnosprawnościa [Family with the child with disability] (pp.167-203). Gdańsk: Wydawnictwo Harmonia.

Tomaszewski, P., Łukaszewicz, A., \& Gałkowski, T. (2000). Rola gestów i znaków migowych w rozwoju twórczości językowej dziecka głuchego [Role of gestures and signs in linguistic creativity development in the deaf child]. Audiofonologia, 17, 75-86.

Tomaszewski, P. \& Piekot, T. (2015). Język migowy w perspektywie socjolingwistycznej [Sign language from sociolinguistic perspective]. Socjolingwistyka, 29, 63-87. 
Tomaszewski, P., \& Ruszkowska, A. (2014). Analiza zachowań językowych i komunikacyjnych u głuchych i słyszących przedszkolaków w sytuacji zabawy [Analysis of Linguistic and communicative behaviors in deaf and hearing preschoolers in play situation]. In M. Sak (Ed.), Deaf Studies w Polsce. Tom 1 [Deaf Studies in Poland. Volume 1] (pp. 171-201). Łódź: Polski Związek Głuchych Oddział Łódzki.

Tomaszewski, P., \& Sak, M. (2014). Is it possible to educate deaf children bilingually in Poland? In M. Olpińska-Szkiełko \& L. Bertelle, (Eds.), Zweisprachigkeit und Bilingualer Unterricht (pp. 129-149). Frankfurt: Peter Lang.

Tomaszewski, P. \& Wieczorek, R. (2016). Kropla drąży skałę. Ku depatologizacji głuchoty [Constant dropping wears away a stone. Towards the depatologization of deafness] In H. Wrona-Polańska, E. Pisula, K. BargielMatusiewicz (Eds.), Zdrowie i choroba. Funkcjonowanie psychospołeczne $i$ zawodowe [Health and disease. Psychosocial and professional functioning] (pp. 153-174). Warszawa: Wydawnictwo Uniwersytetu Warszawskiego.

Tomaszewski, P. Moroń, E. (2018). Quo vadimus? Dynamika paradygmatów głuchoty we współczesnym świecie [Quo vadimus? Dynamics of deafness paradigms in the modern world]. In J. Kowalska, R. Dziurla, \& K. BargielMatuszewicz (Eds.), Kultura, rehabilitacja i zdrowie [Culture, rehabilitation and health] (pp. 61-85). Warszawa: Wydawnictwo Uniwersytetu Warszawskiego.

Weisel, A., Most, T., \& Michael, R. (2007). Mothers' stress and expectations as a function of time since child's cochlear implantation. Journal of Deaf Studies and Deaf Education, 12(1), 55-64.

Wheeler, A., Archbold, S. M., Hardie, T., \& Watson, L. M. (2009). Children with cochlear implants: The communication journey. Cochlear Implants International, 10(1), 41-62.

Wilbur, R. B. (2000). The use of ASL to support the development of English and literacy. Journal of Deaf Studies and Deaf Education, 5(1), 81-104.

Wojda, P. (2010). Trasmission of Polish sign systems. In D. Brentari (Ed.), Sign languages (pp. 131-147). Cambridge, UK: Cambridge University Press.

Wojda, P. (2014). Język migowy w Polsce - jeden czy w wielu odmianach? Przesłanki do badań nad głuchotą [Sign language in Poland: One or many varieties? The rationale for research on deafness]. In M. Sak (Ed.), Deaf Studies w Polsce. Tom 1 [Deaf Studies in Poland. Volume 1] (pp. 202-218). Łódź: Polski Związek Głuchych Oddział Łódzki.

Wrześniewska-Pietrzak, M. (2017). Aksjologiczne wyznaczniki tożsamości w wypowiedziach gluchych i czasopiśmie środowiskowym "Świat Ciszy" [Axiological indicators of identity in texts written by deaf people and in "Świat Ciszy" community newspaper]. Poznań: Wydawnictwo Rys.

Vernon, M., Koh, S. D. (1970). Early manual communication and deaf children's achievement. American Annals of the Deaf, 115(5), 527-537. 
Volterra, V. \& Erting, C. J. (Eds.). (1994). From Gesture to Language in Hearing and Deaf children. Washighton, DC.: Gallaudet University Press.

Yoshinaga-Itano, C. (2006). Early identification, communication modality, and the development of speech and spoken language skills: Patterns and considerations. In M. Marschark \& P. E. Spencer (Eds.), Advances in the Spoken Language of Deaf and Hard-of-Hearing Children (pp. 298-327). New York, NY: Oxford University Press.

Yoshinaga-Itano, Ch. (2013). Principles and guidelines for early intervention after confirmation that a child is deaf or hard of hearing. Journal of Deaf Studies and Deaf Education, 19(2), 143-175.

Yoshinaga-Itano, C., \& Sedey, A. (2000). Early speech development in children who are deaf or hard of hearing: Interrelationships with language and hearing. The Volta Review, 100(5), 181-211 